See Article page e493.

\section{Commentary: Preventive treatment of right-sided heart failure before adulthood?}

\author{
Ari A. Mennander, MD, PhD
}

Some cardiac dysfunction develops early before leading to cardiac failure. Increased ventricular pressure load leads to right-sided heart failure and determines outcome in many congenital heart diseases, including pulmonary hypertension and hypoplastic left heart syndrome. ${ }^{1,2}$ Treatment options are scant since the chronic nature of pressure overload induces often irreversible remodeling of the heart.

Bossers and colleagues ${ }^{3}$ present an experimental model to study the interaction of meuregulin-1 during the development of right-sided heart failure in rat pups. Neuregulin-1 is an endothelial cell-derived growth factor that is essential to functional and structural development of the heart, including cardiomyocyte antiadrenergic and antiapoptotic effects. ${ }^{4}$ Pulmonary artery banding was done in a controlled fashion, which resulted in a reproducible range of cardiac dysfunction. Neuregulin-1 was administrated intraperitoneally, the rats were humanely killed after due follow-up, and echocardiography, histology, immunohistochemistry, and gene expression results were analyzed. The aim was to assess the adaptation to pulmonary artery pressure load in the postnatal phase and to investigate the effects of neuregulin-1 on developing right-sided heart failure.

As compared with controls, pressure load of the right ventricle increased in the banded pups, resulting in reduced cardiac index and increased cardiac stroke volume, all of which led to clinical signs of right-sided dysfunction, increased fibrosis, and changes in cardiomyocyte cellcycle activity. Markers of cardiac and oxidative stress increased during pressure load. Temporary cardiomyocyte

\footnotetext{
From Tampere University Heart Hospital and Tampere University, Tampere, Finland. Disclosures: The author reported no conflicts of interest.

The Journal policy requires editors and reviewers to disclose conflicts of interest and to decline handling or reviewing manuscripts for which they may have a conflict of interest. The editors and reviewers of this article have no conflicts of interest.

Received for publication Nov 1, 2021; revisions received Nov 1, 2021; accepted for publication Nov 1, 2021; available ahead of print Nov 4, 2021.

Address for reprints: Ari A. Mennander, MD, PhD, Tampere University Heart Hospital, SDSKIR, PL 2000, Tampere, Finland (E-mail: ari.mennander@sydansairaala. fi).

J Thorac Cardiovasc Surg 2022;164:e511-2

$0022-5223 / \$ 36.00$

Copyright (C) 2021 by The American Association for Thoracic Surgery

https://doi.org/10.1016/j.jtcvs.2021.11.001
}

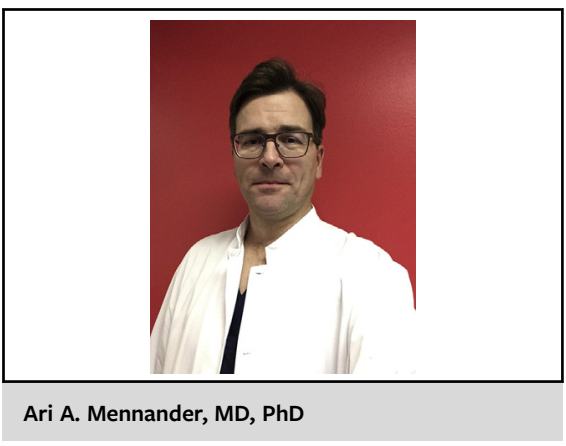

CENTRAL MESSAGE

When would it be safe to treat

right-sided heart failure with

neuregulin-1, which interacts with

cardiomyocyte cell-activation?

cell-cycle, metabolism, and immunity-related genes reflected the development of right-sided heart failure. Neuregulin-1 treatment of banded pups adapted cardiomyocytes to enhanced cell-cycle activation, delayed fibrosis, and improved cardiac function.

The project was logically written and clear. An excellent video clip was provided to show the elegant technique of the pulmonary artery banding in a standardized fashion. The model described cardiac remodeling from rat childhood until early stages of right-sided heart failure. The authors concluded that neuregulin-1 may provide a means to delay the onset of right-sided heart failure after pulmonary pressure load.

In contrast, neuregulins participate in the regulation of cell survival and proliferation also in cancer cells and neural cells. ${ }^{5}$ Neuregulin-1 may include dualistic development of fibrosis including both adaptive and maladaptive responses to heart failure and cardiomyocyte cell-cycle activation without progression to actual mitosis during cardiac remodeling. The authors interpret the described gene expressions at different time points as part of metabolism, maturation, cell-cell activation, and immunity, but are the molecules reflecting the state of cardiac remodeling or the effect of neuregulin-1 itself?

Previously, progression of experimental heart failure induced by aortic stenosis was associated with both the activation and inactivation of neuregulin-1-related molecular interactions in a time-dependent fashion. ${ }^{6}$ Similarly, Bossers and colleagues ${ }^{3}$ hint that there is an effective treatment time window to postpone the onset of right-sided heart failure. Since the consequences of right ventricular pressure 
load are difficult to treat once right-sided heart failure has occurred, it may be worth aiming medical treatment already at the very early phase of childhood. Plausible neurotoxicity of early neuregulin-1 administration would also be interesting to study before heart failure.

\section{References}

1. Oakland H, Joseph P, Naeije R, Elassal A, Cullinan M, Heerdt PM, et al. Arterial load and right ventricular-vascular coupling in pulmonary hypertension. J Appl Physiol. 2021;131:424-33.

2. Schlangen J, Fischer G, Petko C, Hansen JH, Voges I, Rickers C, et al. Arterial elastance and its impact on intrinsic right ventricular function in palliated hypoplastic left heart syndrome. Int J Cardiol. 2013;15:5385-9.
3. Bossers GPL, Günthel M, van der Feen DE, Hagdorn QAJ, Koop A-MC, van Duijvenboden K. Neuregulin-1 enhances cell-cycle activity, delays cardiac fibrosis and improves cardiac performance in rat pups with right ventricular pressure load. J Thorac Cardiovasc Surg. 2022;164:e493-510.

4. Lemmens K, Doggen K, De Keulenaer GW. Role of neuregulin-1/ErbB signaling in cardiovascular physiology and disease. Implications for therapy of heart failure. Circulation. 2007; 116:954-60.

5. Zhao WJ, Schachner M. Neuregulin 1 enhances cell adhesion molecule L1 expression in human glioma cells and promotes their migration as a function of malignancy. J Neuropathol Exp Neurol. 2013;72:244-55.

6. Rohrbach S, Yan X, Weinberg EO, Hasan F, Bartunek J, Marchionni MA, et al. Neuregulin in cardiac hypertrophy in rats with aortic stenosis: differential expression of erbB2 and erbB4 receptors. Circulation. 1999;100:407-12.

7. Xu H-Y, Sun Y-J, Sun Y-Y, Wu Y-J, Xu M-Y, Chen L-P, et al. Lapatinib alleviates TOCP-induced axonal damage in the spinal cord of mouse. Neuropharmacology. 2021;15:1-9. 